\title{
Effect of Microwave-Assisted Processing of Mustard Meal on Physicochemical and Sensory Properties of Cookies
}

\author{
D. Goswami ${ }^{1,2 *}$, S. Sharma ${ }^{1}$, B. Singh ${ }^{1}$ and S. K. Tyagi ${ }^{2}$ \\ ${ }^{1}$ Department of Food Science and Technology, Punjab Agricultural University, \\ Ludhiana-141 004, Punjab, India \\ ${ }^{2}$ Food Grains and Oilseeds Processing Division, ICAR-Central Institute of Post Harvest \\ Engineering and Technology, Ludhiana-141 004, Punjab, India \\ *Corresponding author
}

\section{A B S T R A C T}

Ke y w o r d s
Mustard meal,
Protein rich
cookies,
Antinutritional
factors, Spread
ratio, color value

\section{Keywords}

Mustard meal, Protein rich cookies Antinutritional factors, Spread Article Info

Accepted:

Available Online:

10 September 2020
In the present study microwave assisted processing of mustard meal was done in order to reduce its selected anti-nutritional components. The processed mustard meal (PMM) was then evaluated for partial replacement $(2.5,5$ and $7.5 \%)$ of wheat flour in the cookies formulation and the effect of incorporation on the physicochemical and organoleptic properties were determined. Cookies with wheat flour only were considered as control. With increasing level of PMM the diameter, thickness, $\mathrm{L}^{*}$ value and hardness decreased whereas the spread ratio was increased. Diameter of the cookies varied from $57.40 \mathrm{~mm}$ to $61.67 \mathrm{~mm}$ and the spread ratio of cookies varied from 5.95 to 6.57 with incorporation of PMM. Thickness of cookies decreased from $10.37 \mathrm{~mm}$ in control to $8.81 \mathrm{~mm}$ with increasing level of PMM. Sensory evaluation indicated that the PMM based cookies were acceptable up to $2.5 \%$ replacement level (OAA score 7.30 ) only. Above 5\% PMM replacement levels, the sensory scores for overall acceptability and all the sensory qualities evaluated decreased steadily. The nutritional analysis of cookies showed that protein, ash and crude fat contents were higher in $2.5 \%$ PMM incorporated cookies than control cookies.

\section{Introduction}

Indian mustard (Brassica juncea), commonly known as Rai, or Laha is one of the major oilseed crops of the rapeseed/mustard group. In India, it is the most important oilseed crop after soybean and groundnut with 7.375 million tons production out of total oilseeds production of 26.73 million tons. It is cultivated mainly for oil purpose. Mustard seed contain $30-45 \%$ oil. After extracting the oil from the seed, about 60 per cent of residue is left as cake. Mustard meal left after oil extraction is a good source of protein (28-36 per cent) with excellent nutritional quality (Das et al., 2009). Looking into the shortage of edible proteins in India and increasing trend of its population, diversification of this by-products i.e. mustard cake/meal towards food uses is essential to meet the protein demand. Utilization of mustard meal as a protein source is limited in food products 
because of the anti-nutritional factors such as glucosinolates (Tripathi and Mishra, 2007), phytates (Rutkowski and Kozlowska, 1979) and polyphenolics such as tannins (Sosulki, 1979). Hence, a comprehensive detoxification method has been developed to prepare Processed Mustard Meal (PMM).

Bakery products are generally used as a carrier for incorporation of different nutritionally rich ingredients for their diversification. Consumers demand healthier bakery products and some of the popular trends in the market are the introduction of low/light, functional, natural and organic products (Jamuna and Suresha, 2012). Cookies have become one of the most potential in this regard due to convenience, long shelf-life and ability to serve as a vehicle for important nutrients (Akubor, 2003; Honda and Jood, 2005). The principal ingredients are used in preparation of cookies are wheat flour. However, cookies are being prepared with fortified or composite flour to increase its nutritive value.

The present study was to investigate the effect of partial replacement of wheat flour with mustard meal, obtained after microwaveassisted processing for reduction of selected anti-nutritional components, in different quality characteristics of cookies.

\section{Materials and Methods}

\section{Preparation of Mustard Meal}

Indian mustard (cv PBR 91) seeds procured from Department of Plant Breeding and Genetics, PAU, Ludhiana (India), were cleaned and conditioned to a final moisture content of 10 per cent. Defatted mustard meal $(\approx 1 \%$ fat $)$ was prepared by oil expelling in a Mini oil mill (Komet, CA59G, Germany) followed by repeated solvent extraction using $n$ hexane. The microwave- assisted processing of the defatted mustard meal for reduction of selected anti-nutritional components was carried out under optimized condition (unpublished data). The meal was soaked in water ( $\mathrm{pH} \mathrm{5)}$ in a meal-to-water ratio of 1:18 for $8 \mathrm{~h}$ and the soaking water was filtered. The residue left was subjected to microwave treatment for 3 min using a microwave (Model MS2347BS, LG, India) running at a frequency of $2450 \mathrm{MHz}$ and a medium power of $800 \mathrm{~W}$. The material was dried at $60^{\circ} \mathrm{C}$ to around $10 \%$ moisture content in a tray dryer. The dried material was cooled and pulverized into flour.

\section{Determination of anti-nutritional components of PMM}

The glucosinolates (GSLs) content was determined according to the method of Kumar et al., (2004) with little modification. In a screw-capped tube, meal sample $(0.2 \mathrm{~g})$ along with $0.3 \mathrm{ml}$ of $60 \%$ methanol was heated in a water bath $\left(80^{\circ} \mathrm{C}, 5 \mathrm{~min}\right)$ till complete evaporation of alcohol and cooled. After addition of $4 \mathrm{ml}$ distilled water, the contents again heated $\left(80^{\circ} \mathrm{C}, 15 \mathrm{~min}\right)$, cooled and centrifuged (4000 rpm, $20 \mathrm{~min}$ ). In a test tube $40 \mu \mathrm{l}$ of supernatant and $4 \mathrm{ml}$ of $0.2 \mathrm{mM}$ sodium tetrachloropalladate solution mixed. After $1 \mathrm{~h}$ the absorbance was recorded at 405 $\mathrm{nm}$ and the glucosinolates content was expressed as $\mu$ moles/g defatted meal against the standard of sinigrin. Minimum three replicates were assayed. The Folin-Ciocalteau method of Swain and Hillis (1959) was used for the determination of total phenol content (TPC) as gallic acid equivalent (mg/g).

\section{Preparation of cookies}

Cookies were prepared with the formulation as given in Table 2, by progressively replacing refined wheat flour $(0-7.5 \%)$ with processed mustard meal in the formulation. Shortening and sugar was creamed at low 
speed for 3 min. Dextrose solution was added and mixed at low speed. All the flour and dry ingredients were added and mixed for $2 \mathrm{~min}$ at low speed to form dough. The dough was sheeted to a uniform thickness $(5 \mathrm{~mm})$ using a metal frame. The dough was cut using a cookie cutter and excess dough was discarded. The cookies were baked at $205{ }^{\circ} \mathrm{C}$ for $10 \mathrm{~min}$. The cookies were cooled and packed in polypropylene bags. Effect of incorporation of processed mustard meal on various quality parameters of cookies was then assessed.

\section{Physical parameters}

The diameter, thickness, spread ratio and \% spread factor of cookies were estimated as per AACC (1976) methods. Diameter and thickness of cookies was determined for calculating the spread ratio. Cookies were laid edge to edge and the diameter was measured. These were then rotated at $90^{\circ}$ and average diameter of 6 cookies was recorded. For the thickness measurement 6 cookies were stacked one over another and the thickness was recorded. The cookies were then reshuffled to get the average thickness correctly. Spread ratio of cookies was determined by dividing the diameter with thickness.

\section{Hardness}

Hardness of cookies samples was determined as cutting strength using texture analyzer (Model TA HDi, Stable Micro Systems Ltd.) at load cell of $250 \mathrm{~kg}$. The maximum force (N) required to cut the sample was determined by using Blade set with Warner Bratzler and the force in compression was measured. The test was performed with pre and post test speed of $2 \mathrm{~mm} / \mathrm{s}$, test speed $1 \mathrm{~mm} / \mathrm{s}$ and test distance of $5 \mathrm{~mm}$. The force-time curve was recorded and from this curve the values for peak force recorded and expressed as hardness of the cookies. Three replications of the expanded snacks were measured.

\section{Color}

The color was determined in terms of $\mathrm{L}^{*}, \mathrm{a}^{*}$ and $b^{*}$ values with the help of HunterLab miniScan XE Plus colorimeter (Model 45/0L, HAL, USA) having $25 \mathrm{~mm}$ port size. Color values recorded at two different points. The $\mathrm{L}^{*}, \mathrm{a}^{*}$ and $\mathrm{b}^{*}$ values were further used to compute the total color difference $\left(\Delta \mathrm{E}^{*}\right)$ as follows: $\Delta \mathrm{E}^{*}=\left[\left(\Delta \mathrm{L}^{*}\right)^{2}+\left(\Delta \mathrm{a}^{*}\right)^{2}+\left(\Delta \mathrm{b}^{*}\right)^{2}\right]^{1 / 2}$

\section{Sensory acceptability}

The resultant cookies were evaluated for their sensory acceptability in terms of appearance, texture, flavour, taste and overall acceptability. The samples were coded with random 3 digit numbers and presented before the sensory panel comprising of 10 semi trained persons aged between 25 and 50 . Water was also provided to panellists for rinsing the mouth in between the evaluation of different samples. The panellists were asked to score the product attributes on a Nine point Hedonic scale.

\section{Proximate composition}

The proximate composition of PMM, control cookies and the 2.5\% PMM incorporated cookies (OAA score 7.30) was determined by using the standard AACC (2000) methods.

\section{Statistical analysis}

The analysis was performed at least in triplicate and results were expressed as means along with standard deviation. The significant difference between the samples $(\mathrm{P}<0.05)$ was determined with the help of analysis of variance (ANOVA) test using SPSS, Version 20 statistical software. In case of significant differences Tukey's Multiple Comparison 
Test was applied to determine mean values which differ significantly $(\mathrm{P}<0.05)$ from others.

\section{Results and Discussion}

\section{Chemical composition of processed mustard meal}

The chemical composition of processed mustard meal (PMM) was determined and the Table 1 presents the obtained values. Processing of defatted mustard meal decreased the glucosinolates content from $53.87 \mu$ moles glucosinolates/g defatted meal in the untreated meal to $9.53 \mu$ moles $/ \mathrm{g}$ defatted meal in PMM. The total phenol content also decreased from $28.73 \mathrm{mg} / \mathrm{g}$ to $16.54 \mathrm{mg} / \mathrm{g}$ after processing.

\section{Physical properties of mustard meal based cookies}

The cookies were analyzed for diameter and thickness from which the spread factor was calculated. Hardness of the resultant cookies was also determined. The data regarding physical properties such as diameter, thickness, spread ratio, spread factor and hardness of cookies is presented in Table 3 .

It was observed that incorporation of PMM caused statistically significant $(\mathrm{P}<0.05)$ reduction in diameter of cookies even at $2.5 \%$ $(59.67 \mathrm{~mm})$ level. The lowest value of diameter was observed in case of cookies prepared by incorporation of $7.5 \%$ PMM. Percent decrease in diameter of $2.5 \%$ PMM cookies was $0.11 \%$ when compared with control. Protein from PMM source might have influenced diameter and spread ratio of cookies. The formation of gluten web during mixing and baking increases viscosity of dough and reduces flow of cookie dough (Miller et al., 1997). Leon et al (1996) also developed inverse correlation between diameter and protein content. Noor Aziah et al (2012) reported that the protein content influences the viscosity of dough cookies. This is because the expansion of gluten protein is not resumed in the making of cookies. The hydration property may be another factor which might have influenced cookie spread. As PMM contain significant amount of crude fiber, it may affect hydration property of dough.

It was observed that the thickness of cookies decreased gradually from $10.37 \mathrm{~mm}$ in control to $8.81 \mathrm{~mm}$ with increasing proportion of PMM. The result showed that thickness value of $2.5 \%$ PMM incorporated cookies was statistically $(\mathrm{P}<0.05)$ similar to control $(10.37 \mathrm{~mm})$. The percent decrease in thickness of $2.5 \%$ PMM cookies was $0.25 \%$ when compared with control. The result may be attributed to dilution of gluten content with incorporation of PMM in the formulation resulting into lesser leavening in the resultant cookies.

The spread ratio was affected by the competition for the available water. The spread ratio of all the PMM incorporated cookies although were statistically $(\mathrm{P}<0.05)$ similar but these were higher than control cookies. The spread factor is highly dependent on the dough viscosity and fiber content. The spread factor of cookies too showed similar trend. The spread factor of control sample was considered as standard (100 \%). In comparison to control sample, there was initial increase in spread factor of cookies with 2.5\% PMM. This initial increase in spread ratio might be due to the combined effect of sugar and fibres in the dough. Among the PMM based samples, the spread factor significantly decreased from 108 to $110.5 \%$ with increased addition of PMM. As the level of PMM increased there was increase in the more water absorbing fibre content compared to sugar content. Increase 
in fibre content retarded the spreading of cookies thus reducing the diameter with subsequent increase in thickness of cookies (Agrahar-Murugkar et al., 2015).

Table.1 Chemical composition of PMM

\begin{tabular}{|l|c|}
\hline \multicolumn{1}{|c|}{ Components } & Processed Mustard meal \\
\hline Moisture (\%) & $8.39 \pm 0.09$ \\
\hline Crude protein $(\%)$ & $30.51 \pm 0.13$ \\
\hline Crude fat $(\%)$ & $0.99 \pm 0.17$ \\
\hline Ash $(\%)$ & $5.48 \pm 0.12$ \\
\hline Carbohydrates $(\boldsymbol{\%})$ & 52.80 \\
\hline Crude fibre $(\%)$ & 21.31 \\
\hline Glucosinolates $(\boldsymbol{\mu m o l e s} / \mathbf{g ~ d e f a t t e d ~ m e a l )}$ & $9.53 \pm 0.42$ \\
\hline Total phenolic content $\mathbf{( m g / g )}$ & $16.54 \pm 0.96$ \\
\hline
\end{tabular}

Table.2 Formulation used for cookie making

\begin{tabular}{|l|c|}
\hline \multicolumn{1}{|c|}{ Ingredient } & Quantity (g) \\
\hline Refined wheat flour & $100 \mathrm{~g}$ \\
\hline Ground sugar & $56 \mathrm{~g}$ \\
\hline Shortening & $42 \mathrm{~g}$ \\
\hline Baking powder & $1 \mathrm{~g}$ \\
\hline Sodium bicarbonate & $1 \mathrm{~g}$ \\
\hline Salt & $0.5 \mathrm{~g}$ \\
\hline Dextrose solution $\mathbf{( 8 . 9}$ g dextrose in $\mathbf{1 5 0} \mathbf{~ m l ~ w a t e r )}$ & $13.4 \mathrm{ml}$ \\
\hline
\end{tabular}

Table.3 Effect of processed mustard meal on physical properties of cookies

\begin{tabular}{|c|c|c|c|c|c|}
\hline \multirow{2}{*}{$\begin{array}{c}\text { PMM } \\
(\mathbf{\%})\end{array}$} & $\begin{array}{c}\text { Diameter } \\
(\mathbf{m m})\end{array}$ & $\begin{array}{c}\text { Thickness } \\
(\mathbf{m m})\end{array}$ & $\begin{array}{c}\text { Spread ratio } \\
\end{array}$ & $\begin{array}{c}\text { \% Spread } \\
\text { factor }\end{array}$ & Hardness (N) \\
\hline $\mathbf{0}$ & $61.67 \pm 0.12^{\mathrm{d}}$ & $10.37 \pm 0.23^{\mathrm{c}}$ & $5.95 \pm 0.13^{\mathrm{a}}$ & $100.0 \pm 0.00^{\mathrm{a}}$ & $6468.20 \pm 92.96^{\mathrm{c}}$ \\
\hline $\mathbf{2 . 5}$ & $59.67 \pm 0.23^{\mathrm{c}}$ & $9.29 \pm 0.12^{\mathrm{b}}$ & $6.43 \pm 0.06^{\mathrm{b}}$ & $108.0 \pm 1.06^{\mathrm{b}}$ & $5541.82 \pm 115.26^{\mathrm{b}}$ \\
\hline $\mathbf{5}$ & $58.53 \pm 0.42^{\mathrm{b}}$ & $8.91 \pm 0.20^{\mathrm{a}}$ & $6.57 \pm 0.08^{\mathrm{b}}$ & $110.4 \pm 1.41^{\mathrm{c}}$ & $5097.54 \pm 215.97^{\mathrm{ab}}$ \\
\hline $\mathbf{7 . 5}$ & $57.40 \pm 0.35^{\mathrm{a}}$ & $8.81 \pm 0.09^{\mathrm{a}}$ & $6.57 \pm 0.06^{\mathrm{b}}$ & $110.5 \pm 0.96^{\mathrm{c}}$ & $5072.96 \pm 100.46^{\mathrm{a}}$ \\
\hline
\end{tabular}

Table.4 Effect of processed mustard meal on color attributes of cookies

\begin{tabular}{|c|c|c|c|c|c|c|}
\hline $\begin{array}{c}\text { PMM } \\
(\mathbf{\%})\end{array}$ & $\mathbf{L}^{*}$ & $\mathbf{a}^{*}$ & $\mathbf{b}^{*}$ & $\mathbf{A E}$ & Chroma $^{\text {* }}$ & Hue $^{\mathbf{0}}$ ) \\
\hline $\mathbf{0}$ & $66.11 \pm 3.04^{\mathrm{d}}$ & $1.09 \pm 1.09^{\mathrm{b}}$ & $29.87 \pm 0.68^{\mathrm{d}}$ & - & $31.63 \pm 0.62^{\mathrm{d}}$ & $70.88 \pm 2.04^{\mathrm{b}}$ \\
\hline $\mathbf{2 . 5}$ & $59.93 \pm 1.38^{\mathrm{c}}$ & $9.51 \pm 0.38^{\mathrm{ab}}$ & $25.07 \pm 0.67^{\mathrm{c}}$ & $7.90 \pm 1.42^{\mathrm{a}}$ & $26.82 \pm 0.58^{\mathrm{c}}$ & $69.21 \pm 1.09^{\mathrm{ab}}$ \\
\hline $\mathbf{5}$ & $57.30 \pm 1.45^{\mathrm{b}}$ & $9.13 \pm 0.87^{\mathrm{a}}$ & $24.15 \pm 0.33^{\mathrm{b}}$ & $10.65 \pm 1.02^{\mathrm{b}}$ & $25.83 \pm 0.47^{\mathrm{b}}$ & $69.31 \pm 1.79^{\mathrm{ab}}$ \\
\hline $\mathbf{7 . 5}$ & $53.03 \pm 1.27^{\mathrm{a}}$ & $8.92 \pm 0.49^{\mathrm{a}}$ & $21.74 \pm 0.30^{\mathrm{a}}$ & $15.49 \pm 1.04^{\mathrm{c}}$ & $23.50 \pm 0.32^{\mathrm{a}}$ & $67.70 \pm 1.17^{\mathrm{a}}$ \\
\hline
\end{tabular}


Table.5 Effect of processed mustard meal on sensory acceptability of cookies

\begin{tabular}{|c|c|c|c|c|c|}
\hline PMM & \multicolumn{5}{|c|}{ Sensory scores of cookies } \\
\hline $\mathbf{\%})$ & Appearance & Texture & Aroma & Taste & OAA \\
\hline $\mathbf{0}$ & $8.10 \pm 0.32^{\mathrm{d}}$ & $8.30 \pm 0.63^{\mathrm{d}}$ & $8.05 \pm 0.69^{\mathrm{b}}$ & $8.05 \pm 0.64^{\mathrm{c}}$ & $8.10 \pm 0.39^{\mathrm{d}}$ \\
\hline $\mathbf{2 . 5}$ & $7.20 \pm 0.35^{\mathrm{c}}$ & $7.15 \pm 0.34^{\mathrm{c}}$ & $7.75 \pm 0.63^{\mathrm{b}}$ & $7.55 \pm 0.50^{\mathrm{c}}$ & $7.30 \pm 0.35^{\mathrm{c}}$ \\
\hline $\mathbf{5}$ & $6.05 \pm 0.64^{\mathrm{b}}$ & $6.30 \pm 0.79^{\mathrm{b}}$ & $6.40 \pm 0.46^{\mathrm{a}}$ & $6.85 \pm 0.24^{\mathrm{b}}$ & $6.30 \pm 0.35^{\mathrm{b}}$ \\
\hline $\mathbf{7 . 5}$ & $5.55 \pm 0.50^{\mathrm{a}}$ & $5.55 \pm 0.44^{\mathrm{a}}$ & $6.10 \pm 0.77^{\mathrm{a}}$ & $5.95 \pm 0.44^{\mathrm{a}}$ & $5.70 \pm 0.35^{\mathrm{a}}$ \\
\hline
\end{tabular}

Table.6 Nutritional composition of Cookies containing the maximum accepted level of processed Mustard meal

\begin{tabular}{|l|c|c|}
\hline Components & Control Cookies & 2.5\% PMM* Cookies \\
\hline Moisture (\%) & $1.85 \pm 0.13$ & $2.87 \pm 0.04$ \\
\hline Protein (\%) & $4.87 \pm 0.01$ & $5.05 \pm 0.05$ \\
\hline Crude fat (\%) & $20.60 \pm 0.14$ & $22.14 \pm 0.21$ \\
\hline Ash (\%) & $0.93 \pm 0.12$ & $1.09 \pm 0.24$ \\
\hline Carbohydrates (\%) & 71.75 & 68.85 \\
\hline
\end{tabular}

Hardness of cookies was significantly decreased from $6468.20 \mathrm{~N}$ in control to $5541.82 \mathrm{~N}$ even at $2.5 \% \mathrm{PMM}$ incorporation level. This result may be attributed to weakening of the cookies structure due to dilution of gluten with PMM incorporation.

\section{Color values of mustard meal based cookies}

The cookies samples were evaluated for their lightness ( $\mathrm{L}^{*}$ value), $\mathrm{a}^{*}$ and $\mathrm{b}^{*}$ values. Values for $\Delta \mathrm{E}$, Chroma and Hue $\left(^{\circ}\right)$ were calculated. Table 4 presents the obtained value for different color attributes. Color appears to be one of the important elements for initial acceptability of cookies. The values $\mathrm{L}^{*}$ and $b^{*}$ decreased from 66.11 to 59.93 and from 29.87 to 21.74 , respectively where as color values of a* increased from 1.09 to 8.92 with increasing level of PMM. The colour values of control samples; L*, a*, b*, Chroma and Hue were observed as 66.11, 1.09, 29.87, 31.63 and 70.88 respectively.
The $\mathrm{L}^{*}$ value of all cookies prepared by incorporating PMM were lower than control sample indicating darker color due to addition of PMM. The positive $a^{*}$ value represents redness of PMM cookies. A positive $b^{*}$ value is a measure of the yellowness and the low $b^{*}$ values indicated darkness of cookies prepared with incorporation of PMM. The darkness of cookies increased with the increase in the proportion of PMM from 2.5 to 7.5 per cent.

The $\Delta \mathrm{E}^{*}$ value for $2.5 \%$ PMM incorporated cookies (7.90) clearly indicated the visible difference in color of the PMM incorporated cookies when compared with control.

\section{Sensory acceptability of mustard meal} based cookies

Table 5 shows sensory scores for the cookies produced by incorporating processed mustard meal (PMM). Incorporation of PMM up to $2.5 \%$ statistically did not affect the sensory score for aroma and taste. However, the 
appearance, texture and OAA were statistically affected even at 2.5\% PMM level. The decrease in appearance score may be due to the darkening of cookies with increasing level of PMM as indicated by the decreasing $\mathrm{L}^{*}$ value of PMM incorporated cookies in Table 4. The score for texture of cookies significantly decreased as PMM proportion increases due to the creation of roughness and dullness of the surface texture. The results may be correlated to the decreasing hardness values for PMM incorporated cookies (Table 3). Panelists described cookies containing high levels of PMM as having a bitter after taste and lacking the characteristic texture of cookies. The bitterness may be attributed to the presence of phenolic compounds in PMM.

\section{Proximate composition of cookies}

The nutritional composition of control cookies and 2.5\% PMM based cookies is given in Table 6. From the Table it can be observed that there was slight increase in the protein and ash content of cookies after the PMM incorporation.

In conclusion the present study showed that mustard meal which was undergone through microwave-assisted processing for reduction of ANFs such as glucosinolates and phenolic compounds could be used for food applications. The PMM could be used for replacement of wheat flour in cookies formulation up to $2.5 \%$ with acceptable sensory scores. The PMM incorporation significantly affected the physical parameters viz. diameter, thickness, spread ratio and hardness. Color of the cookies was also adversely affected. However the comparative nutritional analysis indicated a higher protein and ash content in 2.5\% PMM based cookies than that of control cookies. From the study it may be concluded that mustard meal which usually finds application as animal feed, could be processed in order to enhance its palatability and reduce the ANFs and then be used for replacement of wheat flour in bakery products such as cookies.

\section{References}

AACC. 1976. Approved Methods of American Association of Cereal Chemists. 7th Edn. The Association St. Paul, MN.

AACC. 2000. Approved Methods of American Association of Cereal Chemists. 10th ed. The Association St. Paul, MN.

Agrahar-Murugkar, D., Gulati, P., Kotwaliwale, N., and Gupta, C. 2015. Evaluation of nutritional, textural and particle size characteristics of dough and biscuits made from composite flours containing sprouted and malted ingredients. Journal of Food Science and Technology. 52: 5129-5137.

Akubor, P. 2003 Functional properties and performance of cowpea/ plantain/ wheat flour blends in biscuits. Journal of Plant Food for Human Nutrition. 58: 1-8.

Das, R., Bhattacherjee, C., and Ghosh, S. 2009. Preparation of mustard (Brassica juncea L.) Protein isolate and recovery of phenolic compounds by ultrafiltration. Industrial and Engineering Chemistry Research. 48: 4939-4947.

Hooda, S., and Jood, S. 2005. Organoleptic and nutritional evaluation of wheat biscuits supplemented with untreated and treated fenugreek flour. Food Chemistry. 90: 427-435.

Jamuna, K. V., and Suresha, S. V. 2012. An overview of the bakery industry in India. Food Marketing Technology. 3(9): 4042.

Kumar, S., Yadav, S. K., Chauhan, J. S., Singh, A. K., Khan, N. A., and Kumar, P. R. 2004. Total glucosinolate estimation by complex formation 
between glucosinolates and tetrachloropalladate (II) using ELISA reader. Journal of Food Science Technology. 41: 63-65.

Leon, A. E., Rubiolo, A., and Anon, M. C. 1996. Use of triticale flours in cookies: Quality factors. Cereal Chemistry. 73(6): 779-784.

Miller, R. A., Hoseney, R. C., and Morris, C. F. 1997. Effect of formula water content on the spread of sugar-snap cookies. Cereal Chemistry. 74(5): 669-671.

Noor Aziah, A. A., Mohamad Noor, A. Y., and Ho, L. H. 2012. Physicochemical and organoleptic properties of cookies incorporated with legume flour. International Food Research Journal. 19(4): 1539-1543

Rutkowski, A., and Kozlowska, H. 1979. Chemical constituents and protein food processing of rapeseed. Journal of American Oil Chemist Society 56:475477.

Sosulski, F. W. 1979. Organoleptic and nutritional effects of phenolic compounds on oilseed protein products: A review. Journal of American Oil Chemist Society. 56: 711-715.

Swain, T., and Hillis, W. E. 1959. The phenolic constituents of Prunusdomestica I.- The quantitative analysis of phenolic constituents. Journal of Science of Food and Agriculture. 10: 63-68.

Tripathi, M. K., and Mishra, A. S. 2007. Glucosinolates in animal nutrition: a review. Animal Feed Science and Technology. 132:1-27.

\section{How to cite this article:}

Goswami, D., S. Sharma, B. Singh and Tyagi, S. K. 2020. Effect of Microwave-Assisted Processing of Mustard Meal on Physicochemical and Sensory Properties of Cookies. Int.J.Curr.Microbiol.App.Sci. 9(09): 2439-2446. doi: https://doi.org/10.20546/ijcmas.2020.909.303 